\title{
林順之助 ${ }^{* 1}$ 古川淳二*2 山下晋 三*3
}

\begin{abstract}
要 旨 テレフタロヒドロキサミルクロリドを用いて，不飽和ゴムの加硫を試みた， BR, SBR, IR, NR および EPDM などの純ゴム配合㧍よびカーボンブラック配合について，テレフタロヒドロキサミルクロり ド単独执よび塩化水素受容体などを併用した場合の扣硫性を調べた，またテレフタロヒドロキサミルクロリ ドを配合したゴムシートを強塩基の溶液に浸せきしで加硫する方法に対して検討を加えた。それらの結果， テレフタロヒドロキサミルクロリドは加熱によりあるいは適当な助剤の存在でこれらのゴムを加硫すること がわかった.このことより，これらの条件ドでテレフタロヒドロキサミルクロリドはテレフタロニトリルオ キシドとなり，ゴムを加流するむのと推察された。
\end{abstract}

\section{1. ま $え$ がき}

天然ゴムおよび各種の合成ゴムを加硫するのに多くの 方法があるが，篗者らは前報1 でテレフタロニトリルオ キシドによる新しい加硫方法を報告した，この場合テレ フタロニトリルオキシドの不飽和結合に対する反応性は いちじるしく大で，不飽和度の低いEPDMでも低温, 短時間で效率よく加硫することができる。しかし，低温 で加硫が進行するために，スコーチしやすく、ジェン采 ゴムではすぐれた強度特性交有する加硫物が得難いこと が示された。 ニトリルオキシドの活性走弱劣法とし て，テレフタロニトリルオキシドのフェニレン核に置挨 基を導人する法法と、ニトリルオキシドの合成に沶け る安定な中閒体をゴムに添加し，ゴム中でニトリルオキ シドを生成させて加硫する方法とが考えられる，前者に ついて検討中であるが，後者について夷験を行なっ た。その結果，テレフタロニトリルオキシド合成の中間 体であるテレフタロヒドロキサミルクロリド (THC) が 各種のゴムを扣硫することが明らかになったので報告す る、THC 杜加熱により，あるいは適当な塩化水素受容 体の存在下で, 脱塩化水素されてテレフタロニトリルオ キシド(TNO)になり，ゴムを加硫すると考えられる。

†本報圶〔1,3-双極子付加によるゴムの加硫（第 3 報)」となる

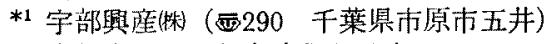

*2 京都大学工学部合成化学教室

*3 京都工芸䋐維大学工芸学部工業化学教室

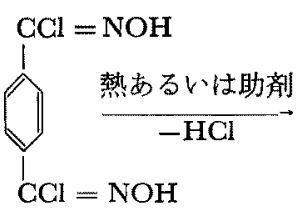

$\mathrm{THC}$<smiles>O/N=C\c1ccc(/C=N\O)cc1</smiles>

TNO

\section{2. 試料および方法}

\section{1 試 料}

テレフタロヒドロキサミルクロリドは前派にしたがっ て合成した。 ベンゼンより再結晶して，無色の針状結晶 を得た。チッ素雾囲気下 DSC（示差走查熱量計）によ

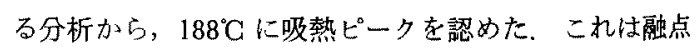
と思われる。（文献值 ${ }^{3)}: \mathrm{mp} .186 \sim 188^{\circ} \mathrm{C}$ ) な拉, 空気 に触机た状態で徐々に界温すると， $240^{\circ} \mathrm{C}$ 以上まで肉眼 ではほとんど変化は認められなかった。この場合は， TNO を経由して，あるいは他の反応でポリマーになっ ていると考えられる。なお，得られた THC の元素分析 值は次の通りであった。

分析值: C, 42.09; H, 2.52; N, 11.81

理論值: $\mathrm{C}, 41.23 ; \mathrm{H}, 2.59 ; \mathrm{N}, 12.02$

使用したゴムは前報で使用したゴムのうちの SBR, BR, NR，IR および EPDMであり，备種添加綝品としては ゴム用薬品あるいは陚薬特級品を用いた。

\section{2 配合および加硫}

テレフタロヒドロキサミルクロリド (THC)をロール を用いて常温でゴムに混練し，熱プレスすることにより 
ゴムを加䟽した，各種ゴムの純ゴムおよびカーボンブラ ック配合物について, THC を変量して, 加硫効果を比 較した. 次に塩化水素受容体として，有機塩基性化合物 や金属酸化物などを添加し，加硫促進效果を調べた，さ らに，浸清加硫法についても検討を加えた。すなわち， THC 配合ゴムをロールを用いて厚さ約 $0.3 \mathrm{~mm}$ のフィ ルムとし,トリェチルアミンのメタノール溶液 (容積比 5：100）に，常温あるいは50Cで浸漬することにより加 硫寸る方法を検討した。

\section{3. 結果および考察}

\section{1 加硫温度の検討}

IR に $2 \mathrm{phr}$ の THC を配合し，120，140および 160 ${ }^{\circ} \mathrm{C}$ で5 60分加硫して得られる加硫物の $300 \%$ 引張応力 を図1に示した。図1加 IR については， $140^{\circ} \mathrm{C} ， 30$ 分程度で十分加硫されることがわかった，前報1の TNOにくらべて，おだやかに反応し，普通のイオウ加 硫に近い温度で加硫することができる。この場合，脱塩 化水素反底が律速になっていると考えられる，塩化水素 ガスの発生は，加硫中ゴムに接触するセロファンがボロ ボロになったり，加硫金型が腐食されることから認めら れた。

\section{2 各種ゴムの加硫}

BR, SBR, IR およびNR について, THC を変量配 合し， $140^{\circ} \mathrm{G} ， 20$ 分のプレス加硫を標準条件として, 加硫したものの $100 \%$ 引張応力を図 2 に示した。 さらに HAF カーボンブラック $40 \mathrm{phr}$ 配合の SBR および NR について，THC を変量配合して加硫したものの $300 \%$

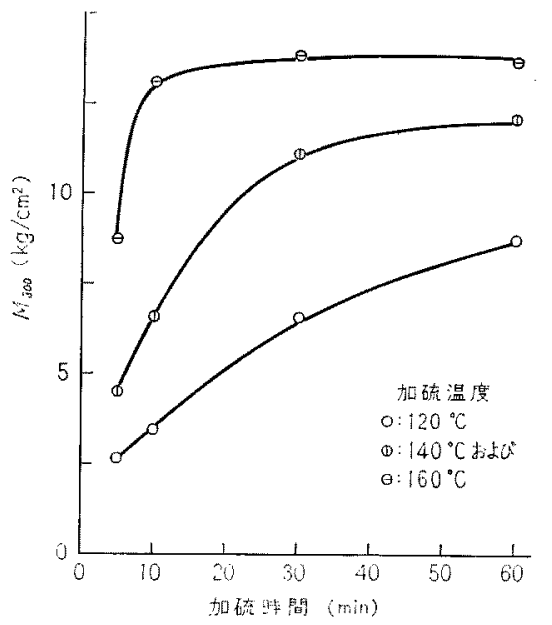

図 1 IR の THG 加硫における加硫温度の効果 : 配合; IR 100, THC 2 (重量部)

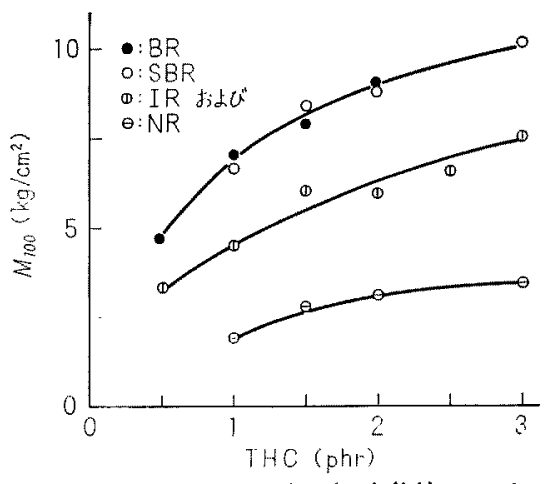

図2各種ゴムの $\mathrm{THC}$ 加硫，加硫条件；140 ${ }^{\circ} \mathrm{C}, 30$ 分

引張応力を図 3 に示した。 これらの結果から，純ゴムの みならずカーボンブラック配合において，ブタジェン系 の BR や SBR は少量の THC で加硫されるのに対 し，イソプレン系の NR P IR は加硫されにくいこと を示している。この差はポリインプレンのメチル基の 立体障害に関保しているようである゙．この上うな傾向 は西多らのニトロンによる加硫に掞いても認められてい る゙、。扔，図2の試料について，前報に準して膨潤法 により網目間鎖数濃度を測定した結果が図4である。横 軸はゴム $1 \mathrm{~g}$ 当りのモル数として, 前報のTNOの結果 も破線で示した。前述のようにBRゃSBRは，TNO の場合と同様効果的に加硫寸るのに対し，IR NR C は効率が悪いことを示している，また，TNO では網目 間鎖数が直線的に堌加するのに対し，THCの場合は飽 和型になっている。こ机らの傾向に対する理由は次のよ うに考えられる，すなわち，THCによる加硫において は生成したTNO がゴムを加硫する反応と，TNO 自体 が重合あるいは他の反応をする可能性がある ${ }^{376)}$. した

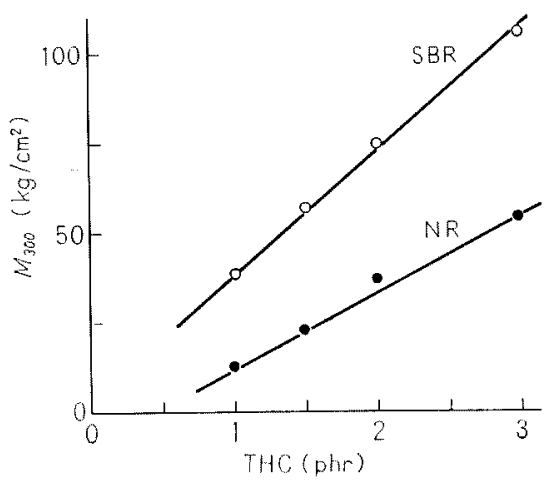

図 3 カーボンブラック配合物の THC 加硫 配合：ゴム100, HAF 400, THC(変量) (重量部), 加硫：140 $\mathrm{C}, 30$ 分 


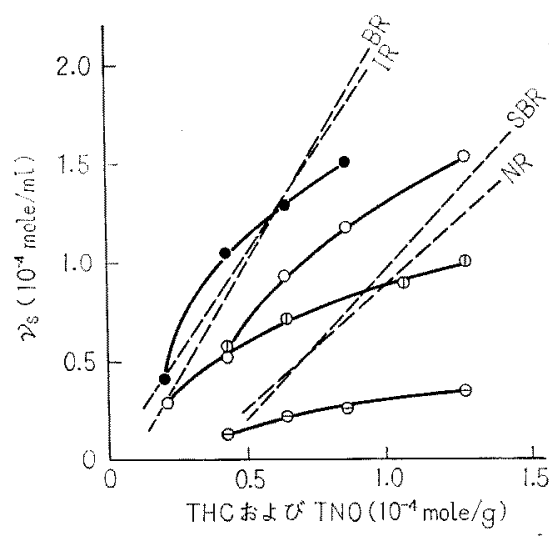

図 4 THC およびTNO 加硫ゴムの網目間鎖数涱度 実線：THC 加硫 破線：TNO 加硫 （図中の記号は図 2 に準ずる）

がって比較的反応しにくいポリイソプレンの場合や，後 記のEPDMの場合では, 重合反応あるいは他の反応が優 先的に起り，加硫が進行しにくいと予想される．また， いずれの場合も図4の上うな飽和型になるのは，嵈度が 高いほど重合しやすくなることを示しているものと考え られる，なお，THCの場合は熱により脱塩化水素され て生成すると考えられる TNO 恃, 結晶状態で涯加され たTNOにくらべて，不安定で重合あるい他の副反応 を行ないやすい状態になっている。したがって TNOで は望ましい加硫反応が進行しやすく，THC の場合は加 硫反応以外の副反応が起りやすいものと推定される。 $\mathrm{SBR}$ の HAF カーボンブラック $40 \mathrm{phr}$ 配合に括いて, THC を変量したときの加硫ゴムの引張特性は図 5 の通 りであった、THC $1 \mathrm{phr}$ 配合で引張強さ $198 \mathrm{~kg} / \mathrm{cm}^{2}$, 伸

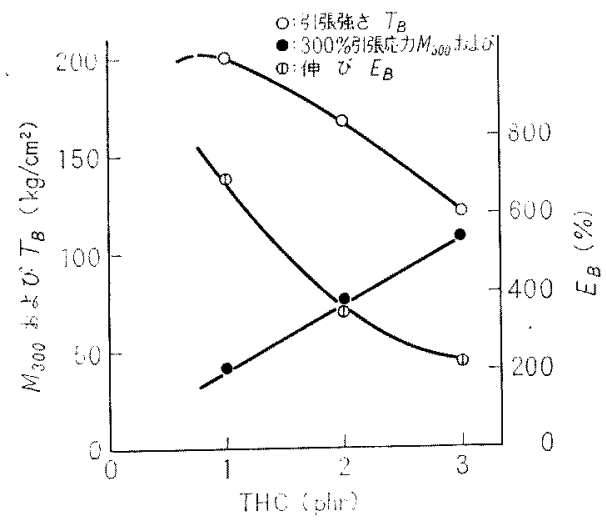

図 5 THC 加硫 SBR の引張特性 配合: SBR 100, HAF 40, THC 変量 加硫: $140^{\circ} \mathrm{C}, 30$ 分
表 I イオウ加硫 SBR の引張特性

配合; SBR 100

$\mathrm{HAF}$ ブラック 40

要鉛華

ステアリン酸 2

イオウ 2

促進剂 $\mathrm{CZ}$

加硫条件； $150^{\circ} \mathrm{C} ， 30$ 分

$300 \%$ 引張応力

$164 \mathrm{~kg} / \mathrm{cm}^{2}$

引張強さ

$245 \mathrm{~kg} / \mathrm{cm}^{2}$

伸び

$400 \%$

び 670\%を示し，表1の普通のイオウ加硫物と大差ない 值を示している，しかし，両者加硫物の破断特性には大 差がないが，THC 加硫物の引張応力が小さい、THC 加 硫ゴムでは絧目密度が小さいとき好ましい破断特性を示 すが，網目密度を増すと引張強さや伸びが小さくなる。 すなわち，引張応力をイオウ加硫物についての值程度ま で增大させると，破断特性は非常に悪くなる。このよう なイオウ加硫物との茽は，橋かけの種類によると考えら れるが，前報のTNOによる加硫で見られたような不均 質な橋かけになっているのかもしれない。扔，EPDM については, THC 単独では満足な加硫が行なわれにく いことがわかった。これに関しては3.3で再び検討する.

\section{3 塩化水素受容体の効果}

3.1で触れたように THCによる加硫においては，脱 塩化水素反応が律速段階になっているようである，こ れに刘し，塩化水素と反応する化合物を添加することに より，反応を促進することが期待される.さらに EPDM については，TNOでは容易に加硫されるのに，THC 単独では加硫されにくい，これに対し EPDMに THC と強塩化水素受容体とを配合し，ゴム中で效果的にTNO を合成することにより EPDM を加硫することができる と期待される。また，CR やエピクロルヒドリンゴムの 加硫におけるように，生成する塩化水素を捕獲し，安定 化することも必要である。このような理由で各種の有機 塩基や金属酸化物その他を添加してゴムの加硫を試み た. 先ず IR の純ゴムおよび SBR のカーボンブラック 配合物の THC 加硫において，尿素の添加効果を調べた 結果が図 6 扩よび 7 である。、ずれの場合も，尿素の 添加量を堌すと加硫が促進されることがわかる，次に EPDMについて検捨した結果は表 2 のおりであった。 寸なわち，THC 単独では発泡状態となり加硫されない が，適当な助䬉の存在で満足な加硫物が得られる，尿素 の他に強塩基のトリエタノールアミンやトリエチルアミ ンについて比較的好ましい結果が得られたが，これらは 
表2 EPDM の THC 加硫における助剂の効果 配合; EPDM 100g, THC $1 \mathrm{~g}$ 加硫策件； $140^{\circ} \mathrm{C}, 30$ 分

\begin{tabular}{|c|c|c|c|c|}
\hline 荗 & & $\begin{array}{c}M_{100} \\
\mathrm{~kg} / \mathrm{cm}^{2}\end{array}$ & $\begin{array}{c}T_{B} \\
\mathrm{~kg} / \mathrm{cm}^{2}\end{array}$ & $\begin{array}{r}E_{B} \\
\% \\
\end{array}$ \\
\hline$m-$ ニロアニリン & $0.01 モ ル$ & & 末加硫 & \\
\hline 防ナチルアミン & " & & $" 1$ & \\
\hline 原素 & " & 4.0 & 9.0 & 700 \\
\hline $\boldsymbol{T}=リ ン$ & " & 3.6 & 4.6 & 900 \\
\hline トリェタノールアミン & $"$ & 5.8 & 9.9 & 450 \\
\hline トリエチルアミン & $"$ & 6.4 & 17.4 & 450 \\
\hline 亜鉛華(ZnO) & $5 \mathrm{~g}$ & 9.3 & 13.6 & 220 \\
\hline 鉛丹 $\left(\mathrm{Pb}_{3} \mathrm{O}_{4}\right)$ & " & 6.5 & [9. 4 & 460 \\
\hline 鉛白 $\left(\mathrm{PbCO}_{3} \mathrm{~Pb}(\mathrm{OH})_{2}\right)$ & $"$ & 9.3 & 25.5 & 270 \\
\hline ステアリン酸亜鉛 & $" \prime$ & 2.7 & 6.5 & 1000 \\
\hline ブランク & - & 3.2 & 6.7 & 1200 \\
\hline
\end{tabular}

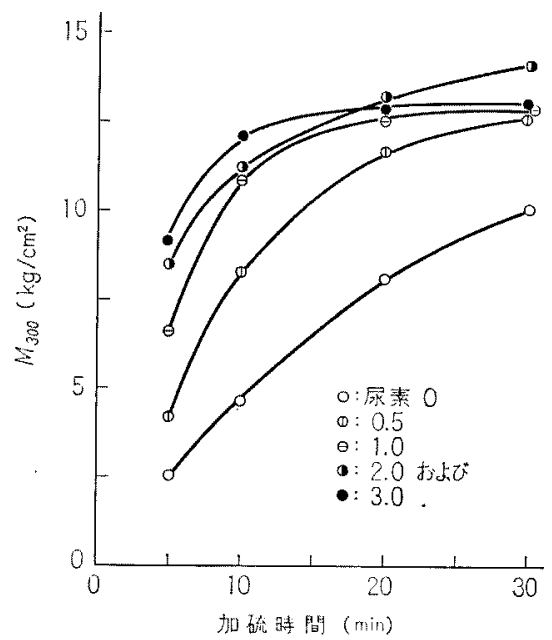

図 6 IR の THC 加硫に捻ける尿素の加硫促 進效果

配合：IR 100，THC2

加硫湿度： $140^{\circ} \mathrm{C}$

液体で配合が困難であるのに対し，覀鉛華，鉛丹扝よび 鉛白などは固体粉末で扱いやすく，効果も優れているこ とがわかったなお，これらの強塩基や金属酸化物など をジエン系ゴムの TNO 加硫に扔いて添加した場合は， 非常にスコーチしやすくなることがわかった。すなわ ち, これらの助片の存在で効果的に TNOが生成してい ると考えられる。

\section{4 漫湴加硫}

3.3 の結果より，THCによる加硫において，強塩 基の存在で THC から脱塩化水素され TNO となり，ゴ ムを加硫すると考えられるが，この方法を浸せき加硫に

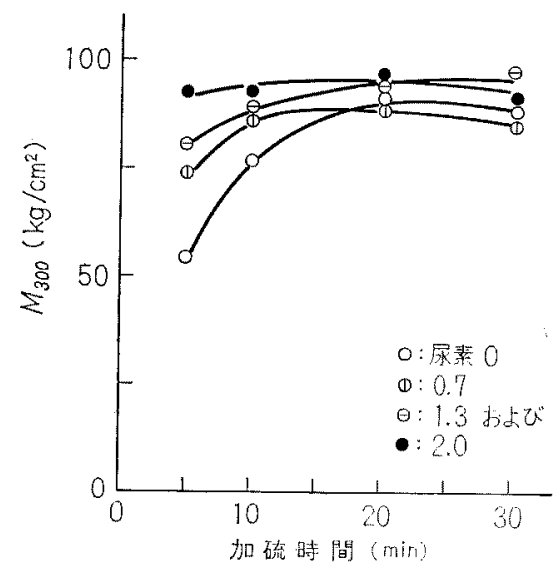

図 7 カーボンブラック 配合 SBR の THC 加 硫に打ける尿素の加硫促進効果

配 合：SBR 100, HAF 40, THC 1.5 加硫温度： $140^{\circ} \mathrm{C}$

応用した，浸せき加硫はゴムのシートを塩化イオウの溶 液に浸せきして加硫する方法”が汾加硫法として知られ ているが，本研究では，THC を配合したゴムを薄いシ 一ト状にして，強塩基の溶液に浸せきすることによりゴ ムの加硫を試みた，SBR の HAF カーボンブラック配 合についての結果を図 8 に示した. $50^{\circ} \mathrm{C}$ において30分程 度で加硫するようである。なお，図中破線で示したよう に，トリエチルアミンが存在しない場合は，3時間後も 加硫はほとんど進行しないことがわかる．EPDM の力

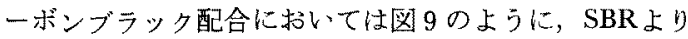
加硫が遅く，2 時間程度かかるようである。なお，SBR，

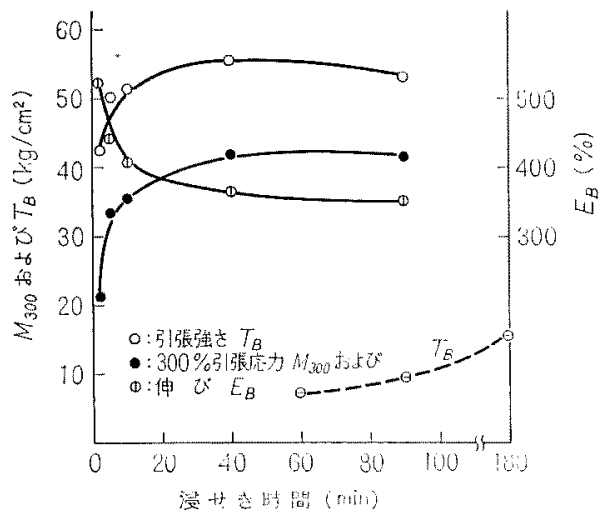

図 8 SBR の浸せき加硫

配 合：SBR 100, HAF 40，THC 1

浸せき温度 : $50^{\circ} \mathrm{C}$

漫せき液：実線，エチルアルコールートリエチルアミン 破線，エチルアルコール 


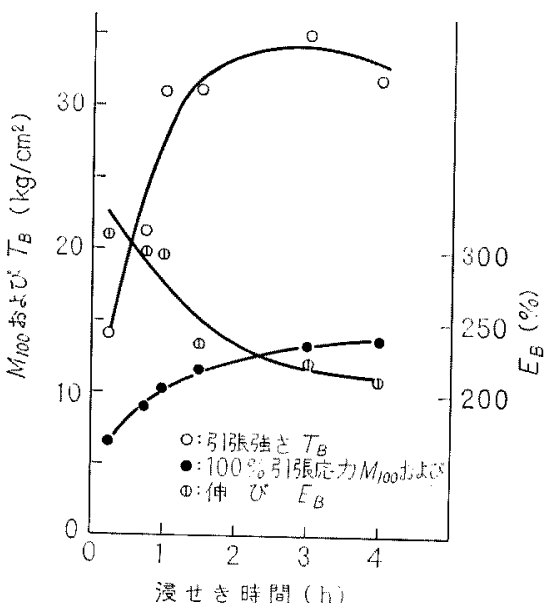

図 9 EPDM の浸せき加硫

配給 : EPDM 100, HAF 40, THC 5

漫せき温度 : $50^{\circ} \mathrm{C}$

浸せき液 : エチルアルコール十トリェチルアシン

EPDM いずれの場合も引張強さが小さいが，これには 2 つの理由が考えられる。すなわち，普通のロールから 作成されたため均質なシートが得られていない，また， THCの融点以下の低温における反忘であるため，THC 質分散のままで加硫していると考えられる。

\section{4. ま と め}

テレフタロヒドロキサミルクロリド (THC)による各 種ゴムの加硫を試みた結果, 次のことがわかった. THC 単独配合ジェン系ゴムは $140^{\circ} \mathrm{C} ， 30$ 分程度で加硫される ことが扐かった。この場合，BRやSBR は効率よく加硫
されるが, IRやNR は比較的加硫されにくい. THC 加 硫に扔いて，適当な有機塩基や金属酸化物などを添加す ることにより，加硫が促進された．これは生成する塩化 水素が捕獲されることによる。块たこの方法で，THC 単独では加硫しにくい EPDM も加硫が可能となった た.さらに，THCを配合したゴムのシートを強塩基の 溶液に浸せきすることによっても加硫することができる ことがわかった，以上の結果，THC は熱によりあるい は適当な助剤の存在で脱塩化水素され，TNOとなりゴ 么を加硫するすのと推察される。

（本研究はゴム研究発表会，名古屋 $(1968 \cdot 10)$ で講 演発表した）

\section{引用 文 献}

1) 林順之助, 古川淳二, 山下晋三：日ゴム拹誌, 43, $313(1970)$

2) R. H. Wiley: Heterocyclic Compounds, Vol. of Five and Six-Membered Compound with Nitrogen and Oxygen. p. 21, Intersci, Pub.

3) C. G. Overberger, S. Fujimoto: J. Polymer Soc., $[C], 16,4161$ (1968)

4) R. Huisgen; Angew. Chem., 75, 742 (1963)

5) 西多貲男, 古川淳二, 山下政三：日ゴム協誌, 43, 307, (1970)

6) Y. Iwakura, M. Akiyama, K. Nagakubo: Bull. Chem., Soc., Japan, 37, 767 (1964)

7) J. Glazer, J. H. Shulman: J. Polymer Sci, 14 225 (1954)

\section{A NOVEL VULCANIŻATION BY 1, 3-DIPOLAR ADDITION (III) VULCANIZATION OF RUBBERS BY TEREPHTHALOHYDROXAMYL CHLORIDE}
J. Hayashi (Ube Industries, Ltd.; Goi, Ichihara-shi, Chiba-ken, 290, Japan.)
J. Furukawa (Department of Synthetic Chemistry, Faculty of Engineering, Kyoto University; Yoshida, Sakyo-ku, Kyoto, 606, Japan.)
S. Yamashita (Department of Chemistry, Kyoto Institute of Technology; Matsugasaki, Sakyo-ku, Kyoto, 606, Japan.)

It was found that terephthalohydroxamyl chloride is able to vulcanize various kinds of rubber having unsaturated double bond. Gum and carbon black stocks of BR, IR, NR and EPDM were used as the rubber samples. Moreover, the vulcanization was also conducted by dipping rubber sheets compounded with terephthalohydroxamyl chloride in triethylamine-alcohol solution.

As the result, it was found that terephthalohydroxamyl chloride is able to vulcanize the rubbers on heating in the presence or absence of hydrogenchloride acceptors, such as urea, triethylamine, zinc oxide and so on. It was considered that terephthalohydroxamyl chloride was converted into terephthalonitrile oxide in the rubbers to produce vulcanizates by 1,3-dipolar addition to the double bonds. 